\title{
Analisis Tingkat Kekakuan Struktur Rangka - Dinding Geser Tanpa Dan Dengan Belt Truss Pada Bangunan Tinggi Beton Bertulang Akibat Beban Lateral
}

\author{
*Yohanes Laka Suku ${ }^{1}$, Fransiskus Xaverius Ndale ${ }^{2}$ \\ ${ }^{1,2}$ Program Studi Teknik Sipil, Fakultas Teknik, Universitas Flores, Ende \\ *) Correspondence, e-mail: mayokonco@yahoo.co.id
}

\begin{abstract}
ABSTRAK
Bangunan tinggi rawan terhadap beban lateral akibat gempa dan angin. Salah satu solusi untuk meningkatkan kinerja struktur bangunan tingkat tinggi dalam menahan beban lateral antara lain yaitu dengan pemasangan dinding geser (shear wall) sebagai sub sistim penahan beban lateral dari sistim struktur untuk manambah kekakuan struktur. Semakin tinggi bangunan maka dinding geser akan menyerap gaya geser yang besar, dan dengan demikian lebar dinding geser akan bertambah besar. Salah satu cara untuk memperkecil lebar diding geser dengan nilai kekuatan yang sama yaitu dengan penambahan outrigger dan belt truss. Penggunaan Sistim Belt Truss pada bangunan tinggi dapat meningkatkan kekakukan struktur dan membuat struktur lebih efficient dibawah pengaruh beban lateral/gempa. Hasil perhitungan untuk struktur gedung 15 lantai ini, didapat bahwa model struktur rangka dinding geser dengan satu belt truss dapat mereduksi simpangan lateral maksimum sebesar $18,5 \%$ dengan penempatan belt truss pada $3 / 4$ tinggi gedung, sedangkan dengan dua belt truss simpangan lateral maksimum yang dapat diredukai sebesar 27,01 \% yakni dengan penempatan belt truss pada lantai atas dan pada $1 / 2$ tinggi bangunan.
\end{abstract}

\section{Kata Kunci : Struktur rangka, Dinding geser, Belt Truss}

\section{PENDAHULUAN}

Bangunan tinggi rawan terhadap beban lateral akibat gempa dan angin. Salah satu solusi untuk meningkatkan kinerja struktur bangunan tingkat tinggi dalam menahan beban lateral antara lain yaitu dengan pemasangan dinding geser (shear wall) sebagai sub sistim penahan beban lateral dari sistim struktur untuk manambah kekakuan struktur. Semakin tinggi bangunan maka dinding geser akan menyerap gaya geser yang besar, dan dengan demikian lebar dinding geser akan bertambah besar. Salah satu cara untuk memperkecil lebar diding geser dengan nilai kekuatan yang sama yaitu dengan penambahan outrigger dan belt truss. Sistim ini sering disebut shearwall-frame-outrigger and belt truss, Sistim ini menghubungkan shearwall dengan kolom eksterior melalui outrigger (lihat gambar 1), dan telah terbukti efektif dapat mereduksi simpangan lateral cukup signifikan (Taranath, 1998). Hasil penelitian serupa dilaporkan oleh Iyengar (1995); Smith,et al (1996); Xiaoxuan Qi dan Shuang Chen (1996); Po Seng Kian dan Siahaan (2001).

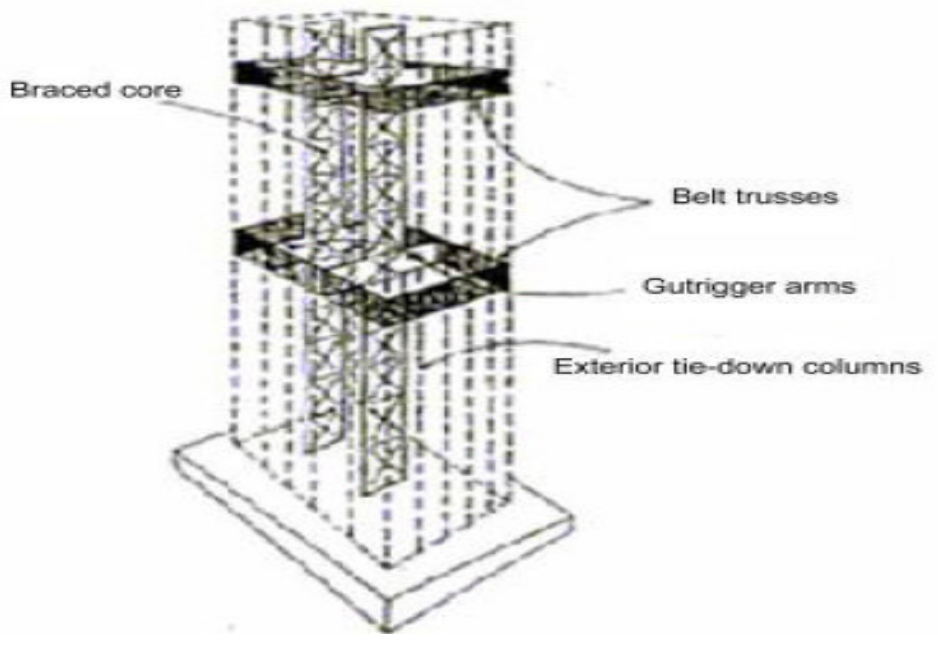

Fakultas Teknik, Universitas Flores, ISSN 1907-5197 


\section{Gambar 1. Sistim Struktur dengan belt truss dan outrigger}

Penambahan outrigger yang menghubungkan shearwall dengan kolom exterior melalui outrigger mempunyai konsekuensi pemanfaatan ruang yang terbatas karena adanya balok outrigger yang besar/raksasa, Untuk mengatasi hal ini Nair (1998) mengusulkan penggunaan sistim struktur belt truss yang dikombinasikan dengan shearwall (shearwall-belt truss) sehingga menjadi suatu sistim struktur yang dinamakan virtual outrigger. Hasil penelitian yang telah dilakukan Nair(1998) dan Lumantarna et. al (1999) diperoleh bahwa sistim struktur shearwall-belt truss ternyata dapat mereduksi simpangan lateral dengan baik.

Berdasarkan latar belakang ini maka dilakukan studi tentang tingkat kekakuan sistim struktur rangka-dinding geser tanpa dan dengan belt truss yang ditempatkan pada lokasi yang berbeda. Pada penelitian ini beban gempa yang digunakan, beban respon spektrum yang diambil dari Tata Cara Perencanaan Ketahanan Gempa Untuk Bangunan Gedung (SNI 03-1726-2002), Bangunan diasumsikan terletak pada wilayah gempa 3 dan dengan jenis tanah lunak dan diperuntukan sebagai gedung sewa. Analisis struktur tiga dimensi menggunkan paket program SAP 2000. Permasalahan dalam peneltian ini adalah bagaimana tingkat kekakuan sistem struktur rangka-dinding geser tanpa dan dengan belt truss yang ditempatkan pada lokasi berbeda pada struktur bangunan gedung sewa berlantai lima belas.

\section{Sistim Struktur Bagunan Tinggi}

Dalam mendisain gedung tinggi, selain bentuk dan tampilannya, struktur juga harus mampu menahan geser dan lentur yang diakibatkan oleh berbagai macam gaya gravitasi (beban hidup dan mati) dan lateral (beban angin atau gempa). Parameter yang digunakan dalam mengukur kinerja dari bangunan tinggi yakni indeks kekakuan lentur (bending rigidity index BRI) dan indeks kekakuan geser (shear rigidity index SRI). Indeks kekakuan lentur (bending rigidity index) adalah total momen inersia dari semua kolom terhadap titik berat dari sistim bangunan (Taranath,1998). Nilai BRI dan SRI dari sistim bangunan sangat bergantung dari penempatan kolom pada sistim bangunan tersebut dimana nilai BRI maksimum yakni 100 apabila penempatan kolom pada sudu-sudut bangunan seperti gambar 2.a. sedangkan nilai SRI maksimum yakni 100 apa bila penempatan kolom seperti pada gambar 2.b.

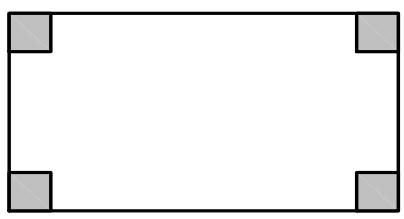

a)

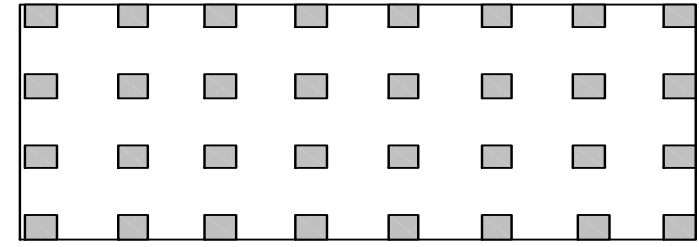

b)

Gambar 2. Denah kolom bangunan: a) NilaiBRI = 100; b) Nilai SRI = 100 (Taranath,1998)

Bangunan tinggi akan berperilaku sebagai balok kantilever vertikal dan riskan terhadap terhadap simpangan/goyangan akibat gaya lateral, oleh karena itu suatu jenis pengaku perlu disediakan dalam arah memanjang dan melintang bangunan guna menyebarkan gaya-gaya lateral ke bidang-bidang vertikal yang diperkaku dan meneruskan gaya-gaya ini ke pondasi. Penyebaran gaya-gaya lateral pada strukur bangunan dapat dilakukan dengan melawan secara terus menerus melalui aksi rangka kaku atau truss dengan bracing, dan dengan memperkaku portal tertentu dari bangunan dengan rangka kaku (outrigger atau belt truss) atau dinding geser (shearwall). Sistim penahan gaya lateral dapat dikelompokan sebagai berikut : Rangka kaku (rigid frame), Dinding Geser (shearwall), Rangka Bracing (braced frame) dan Rangka campuran (mixed frame) 
Taranath (1998) menyatakan bahwa pada sistim rangka kaku gaya-gaya lateral ditahan seluruhnya oleh rangka bangunan, sehingga lendutan lateral rangka kaku disebabkan oleh (lihat gambar 2.2) :

1. Lentur kantilever, dimana ketika melawan momen guling rangka ini berlaku sebagai balok kantilever vertikal yang melentur melalui deformasi aksial serat-seratnya, disini pemanjangan dan pemendekan kolom akan menghasilkan simpangan lateral, dan menyumbang 15-20\% dari penyimpangan total struktur.

2. Defleksi karena lentur balok dan kolom, gaya geser horisontal dan vertikal pada kolom dan balok menyebabkan terjadinya momen lentur, dan apa bila melentur maka seluruh rangka mengalami distorsi. Penyimpangan akibat distorsi/lentur pada balok 50 - $60 \%$ sedangkan distorsi/lentur pada kolom 15 $20 \%$ dari penyimpangan total struktur.

Schueller (1989) menyatakan bahwa prinsip rangka kaku akan ekonomis sampai 30 lantai untuk rangka baja dan sampai 20 lantai untuk rangka beton.
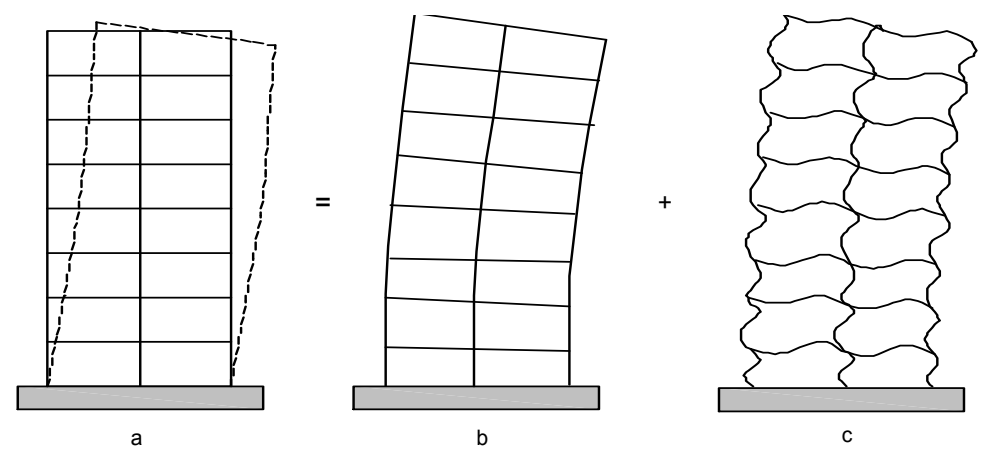

Gambar 3. Defleksi pada Rangka Kaku : (a) Gaya dan Deformasi yang disebabkan oleh momen guling (external
overtuning moment) ; (B) Gaya dan deformasi akibat Geser (external shear)

Berbagai sistim telah dicoba untuk menahan beban lateral, seperti menggunakan dinding geser didalam rangka struktur. Dinding geser dapat dibuat dari beton atau dari rangka baja, bentuknya bisa berupa inti tertutup mengelilingi ruangan lift atau ruangan tangga, atau biasa juga berupa dinding sejajar didalam bangunan. Sisitim dinding geser pada dasarnya dapat dibagi menjadi sistim terbuka dan tertutup. Sistim terbuka terdiri dari unsur linier tunggal atau gabungan unsur yang tidak lengkap melingkupi ruang geometrisnya dan bentuknya adalah $\mathrm{L}, \mathrm{X}, \mathrm{V}, \mathrm{Y}, \mathrm{T}$ dan $\mathrm{H}$. sebaliknya sistim tertutup melingkupi ruang geometris dengan bentuk bujursangkar, segitiga, persegi panjang dan bulat. Fazlur Khan dalam Struktur Bangunan Tinggi (Schueller, 1989) dan Taranath (1998) mengemukakan bahwa Struktur Rangka- Dinding Geser dapat diterapkan pada bangunan sampai 40 lantai.

\section{Sistim Struktur Belt Truss}

Belt Truss (rangka sabuk) merupakan unsur pengaku struktur agar diperoleh struktur yang cukup kaku dan kuat yang ditempatkan pada kolom-kolom eksterior dan mengelilingi gedung disebelah luar. Nair (1998) memperkenalkan belt truss dengan sebutan virtual outrigger karena penempatannya yang tidak berada di tengah denah bangunan tetapi masih tetap berfungsi sebagai outrigger. Taranath (1998) mengatakan bahwa struktur rangka - dinding geser menjadi tidak effisien lagi untuk gedung dengan ketinggian di atas 40 lantai dan effisiensi bangunan akan meningkat sebesar 20 - $30 \%$ jika menggunakan belt-truss horizontal untuk mengikat rangka.

Dasar pemikiran utama dari sistim ini yaitu penggunaan lantai diafragma yang mempunyai kekakuan yang besar pada bidangnya (in-plane stiffness). Untuk mentrasfer momen guling (overtuning moment) yang dialami dinding geser (cor) akibat gaya lateral menjadi gaya kopel horizontal dari dinding geser ke struktur 
rangka batang. Selanjutnya belt truss akan mengkonversi gaya kopel horizontal pada diafragma lantai menjadi gaya kopel vertical pada kolom-kolom eksterior (Nair, 1998).

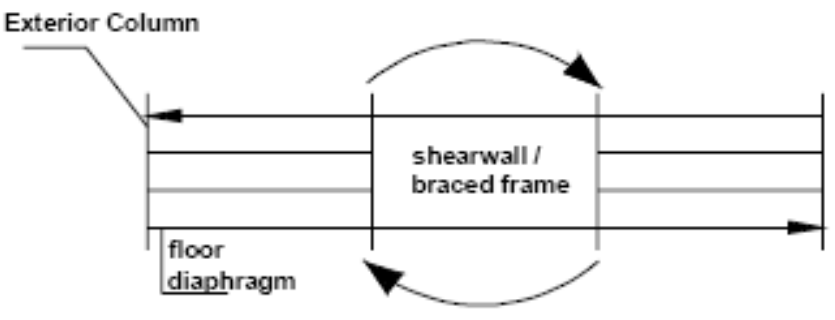

(a)

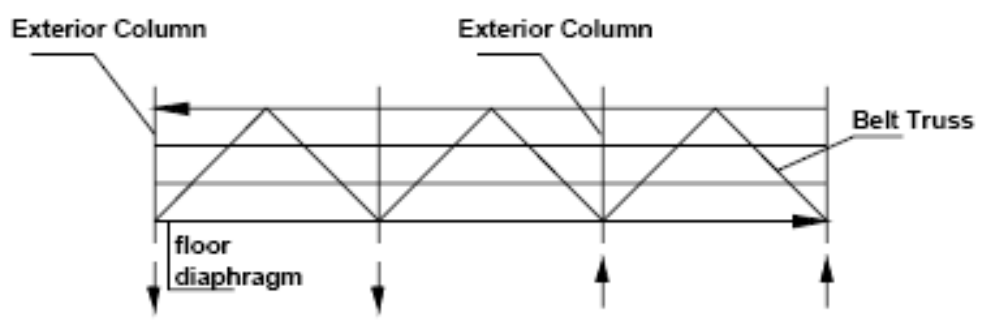

(b)

\section{Gambar 4 (a) Transfer Overtuning Moment dari Dinding Geser ke Diafragma Lantai (b) Tranfer Gaya dari Diafragma Lantai ke Kolom Eksterior}

Pada struktur bangunan dapat ditempatkan satu atau beberapa rangka sabuk (belt truss), lebih banyak rangka yang digunakan lebih memperkaku struktu tersebut. Schueler (1989) menyatakan bahwa penempatan belt truss pada bagian atas dan tengah bangunan cukup ekonomis sampai dengan ketinggia 60 lantai.
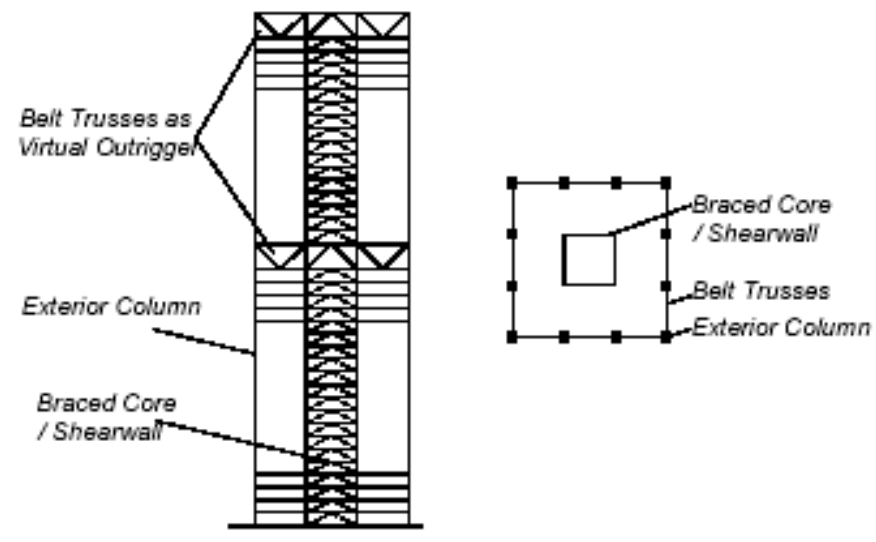

Gambar 5. Visualisai penempatan belt truss

Perilaku struktur rangka - dinding geser - belt truss terhadap pembebanan lateral Gambar 6.a. struktur rangka - dinding geser, akibat beban lateral akan berlaku sebagai kantilever dan bagian atasnya akan bebas berputar (rangka ini hampir tidak melawan gaya rotasi) dan apa bila rangka ini diikat dengan menggunakan belt truss (gambar 6.b)maka rotasi di bagian atas struktur ini akan ditiadakan karena kolom eksterior di ikat oleh belt truss sehinnga tidak timbul memen lentur pada kolom. Kekakuan parsial dari sistim ini tercermin pada diagram momennya. Sistim ini tidak lagi berlaku sebagai kantilever murni karna bagian atasnya terikat dan 
momen lentur pada bagian dasar bangunan berkurang. Kekakuan dan kekuatan dari sistim ini dapat ditingkatkan dengan menambah belt truss pada lantai-lantai diantara struktur bangunan (gambar 6.c).

Tampak bahwa pada setiap tingkat yang dilengkapi dengan belt truss rotasi akan dicegah, dan kekakuan yang terjadi pada tempat-tempat ini akan mengurangi besaran pada diagram momen. Momen lentur pada dasar bangunan akan berkurang lagi karena terjadinya pergeseran gaya lateral kegaya aksial dengan demikian mengurangi besarnya simpangan.

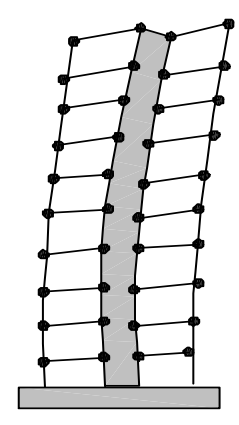

a

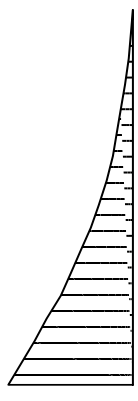

Cambar 4 Perilaku

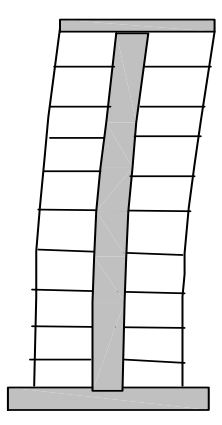

b

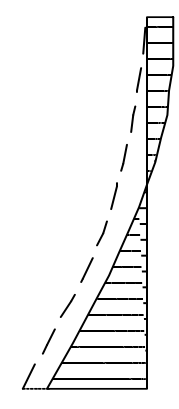

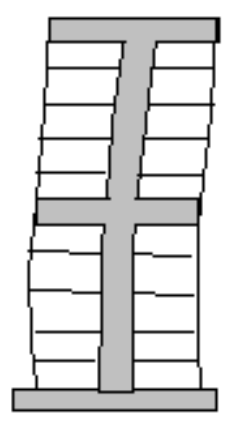

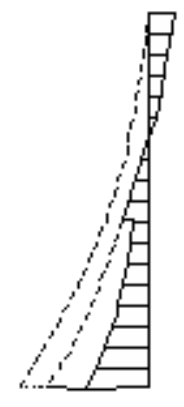

c

Gambar 4 Perilaku Struktur Rangka - Dinding Geser - Belt Truss

\section{Pemodelan dan Analisis Struktur}

Struktur yang ditinjau adalah sebuah gedung sewa berlantai 15 dengan tinggi total 53,5 m, menggunakan system shearwall-frame dengan belt truss sebagai virtual outrigger dan struktur berada diwilayah gempa 3 dan diatas tanah lunak, beban gempa sesuai SNI 03-1726-2002. Pemodelan struktur 3D menggunakan program SAP 2000, secara umum langkah pemodelan meliputi :

1. membuat model

2. mendefenisikan material, penampang, jenis elemen struktur, dan beban

3. memasukan defenisi pada langkah kedua kedalam elemen struktur yang telah dimodel

4. melakukan run analysis

5. menginterprestasi hasil. Adapun dimensi elemen struktur dapat dilihat pada table 1 . 


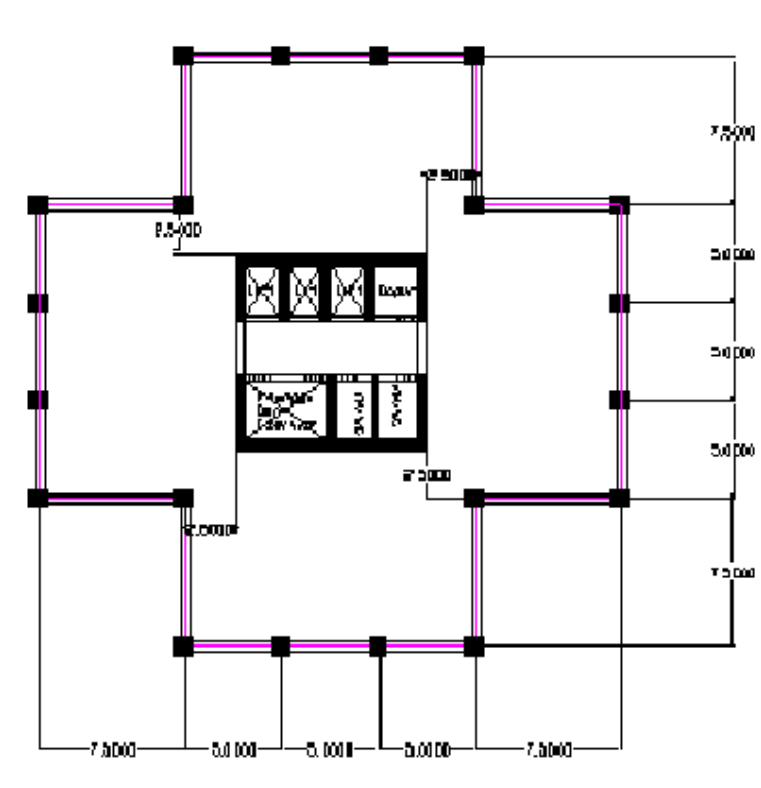

(a)

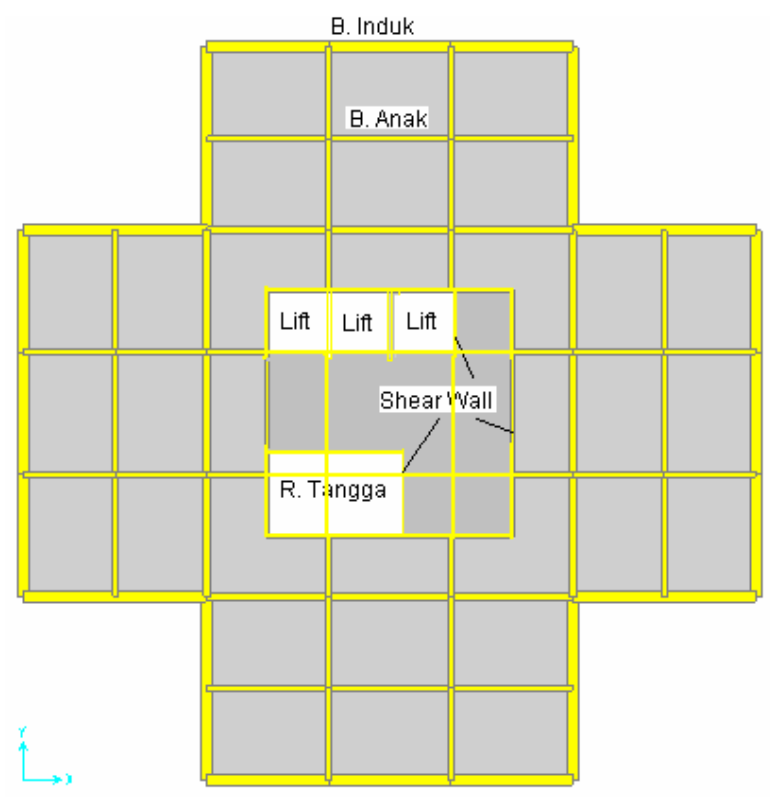

(b)

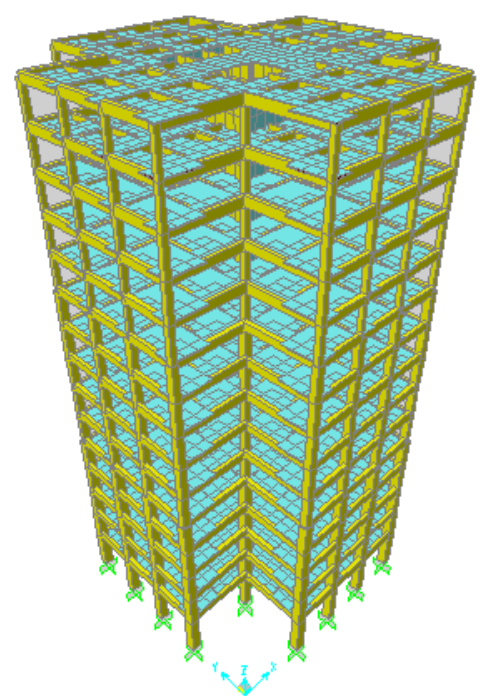

(c)

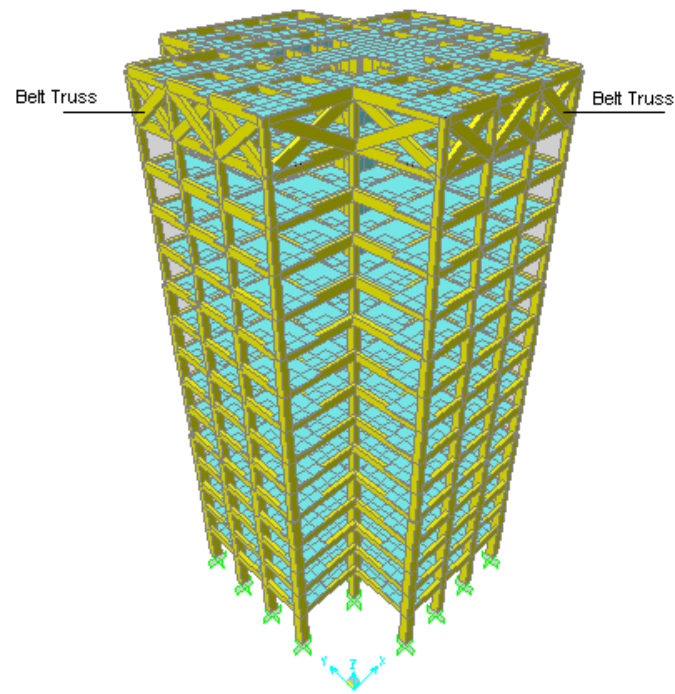

(d)

Gambar 5 (a) Denah lantai tipikal (I-XV), (b) Denah struktur, (c) Struktur shearwall-frame tanpa belt truss, (d) Struktur shearwall-frame dengan satu belt truss pada atas bangunan (antara lantai 14 dan 15)

Model struktur yang akan dianalisa, sehubungan dengan penempatan belt truss pada struktur bangunan adalah sebagai berikut :

1. Model struktur tanpa belt truss (SNB)

2. Model struktur dengan satu belt truss pada atas bangunan (antara lantai 14 dan 15) (SB-Top)

3. Model struktur dengan satu belt truss pada $3 / 4$ tinggi bangunan (antara lantai 11 dan 12) (SB-3/4)

4. Model struktur dengan satu belt truss pada $1 / 2$ tinggi bangunan (antara lantai 7 dan 8 ) (SB-1/2)

5. Model struktur dengan satu belt truss pada $1 / 4$ tinggi bangunan (antara lantai 3 dan 4) (SB-1/4)

6. Model struktur dengan dua belt truss pada atas dan $3 / 4$ tinggi bangunan (SB-Top\&3/4) 
7. Model struktur dengan dua belt truss pada atas dan $1 / 2$ tinggi bangunan (SB-Top\&1/2)

8. Model struktur dengan dua belt truss pada atas dan $1 / 4$ tinggi bangunan (SB-Top\&1/4)

Tabel 1 Dimensi elemen struktur

\begin{tabular}{cc}
\hline Elemen & Keterangan \\
\hline
\end{tabular}

$\begin{array}{ll}\text { A. Tinggi bangunan } & \\ \text { Tinggi tinggkat I } & 4,5 \mathrm{~m} \\ \text { Tinggi tiap tingkat (II-XV) } & 3,5 \mathrm{~m} \\ \text { Tinggi seluruh bangunan } & 53,5 \mathrm{~m} \\ \quad \text { B. Mutu bahan } & 300 \mathrm{MPa} \\ \text { Beton }\left(f^{\prime} c\right) & 400 \mathrm{MPa} \\ \text { Tulangan Longitudinal }\left(f_{y}\right) & 240 \mathrm{MPa} \\ \text { Tulangan Sengkang } & \\ \text { C. Dimensi kolom } & 0,9 \times 0,9 \mathrm{~m}^{2} \\ \text { Tingkat I - V } & 0,7 \times 0,7 \mathrm{~m}^{2} \\ \text { Tingkat VI - X } & 0,5 \times 0,5 \mathrm{~m}^{2} \\ \text { Tingkat XI - XV } & \\ \text { D. Dimensi balok } & 0,4 \times 0,8 \mathrm{~m}^{2} \\ \text { Balok induk } & 0,25 \times 0,5 \mathrm{~m}^{2} \\ \text { Balok anak } & 0,4 \times 0,8 \mathrm{~m}^{2} \\ \text { Belt truss } & 0,3 \mathrm{~m} \times\left(10 \times 10 \mathrm{~m}^{2}\right) \\ \text { E.Dimensi dinding geser } & \end{array}$

Tabel 2. Data Koefisien Gempa Dasar, Wilayah 3, Jenis Tanah Lunak

\begin{tabular}{cc}
\hline $\begin{array}{c}\text { Waktu } \\
\text { Detik }\end{array}$ & Koefisien c \\
\hline 0 & 0,3 \\
0,2 & 0,75 \\
1 & 0,75 \\
2 & 0,375 \\
3 & 0,25 \\
\hline
\end{tabular}

\section{HASIL DAN PEMBAHASAN}

\section{Struktur Dengan Satu Belt Truss}

Simpangan kesamping (lateral displacement) pada setiap tinggi lantai dapat dilihat pada gambar 6. Disini dapat dilihat fungsi belt truss dalam mereduksi simpangan lateral jika dibandingkan dengan struktur tanpa belt truss. Jika dilihat simpangan lateral yang terjadi pada lantai atas maka, untuk pemasangan belt truss pada lantai atas (SB-TOP) simpangan lateral yang direduksi $14 \%$, pemasangan belt truss pada $3 / 4$ tinggi bangunan simpangan lateral yang direduksi $18,5 \%$, pemasangan belt truss pada $1 / 2$ tinggi bangunan simpangan lateral yang direduksi $17,02 \%$, pemasangan belt truss pada $1 / 4$ tinggi bangunan $11,02 \%$. 


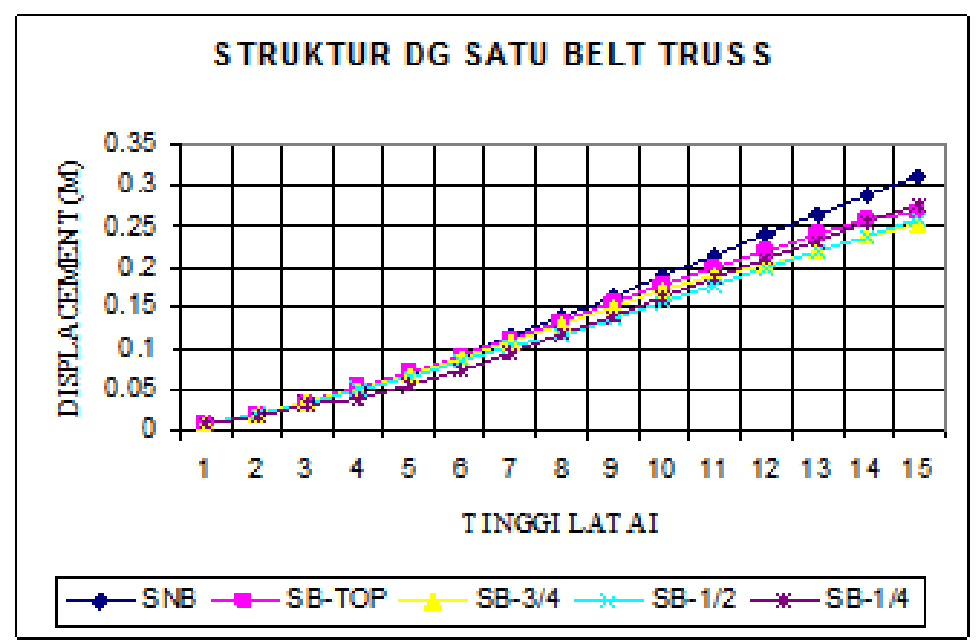

Gambar 6. Simpangan Lateral Model Struktur dengan satu Belt Truss

\section{Struktur Dengan Dua Belt Truss}

Simpangan kesamping (lateral displacement) pada setiap tinggi lantai akibat pemasangan dua belt truss dapat dilihat pada gambar 7. Perbandingan simpangan lateral yang terjadi pada lantai atas akibat pemasangan 2 belt truss terhadap model strutur tanpa belt truss adalah sebagai berikut, untuk pemasangan belt truss pada lantai atas dan $3 / 4$ tinggi bangunan (SB-TOP\&3/4) simpangan lateral yang tereduksi $24,86 \%$, untuk pemasangan belt truss pada lantai atas dan $1 / 2$ tinggi bangunan simpangan lateral yang direduksi $27,01 \%$, untuk pemasangan belt truss pada lantai atas dan 1/4 tinggi bangunan simpangan lateral yang direduksi $24,39 \%$.

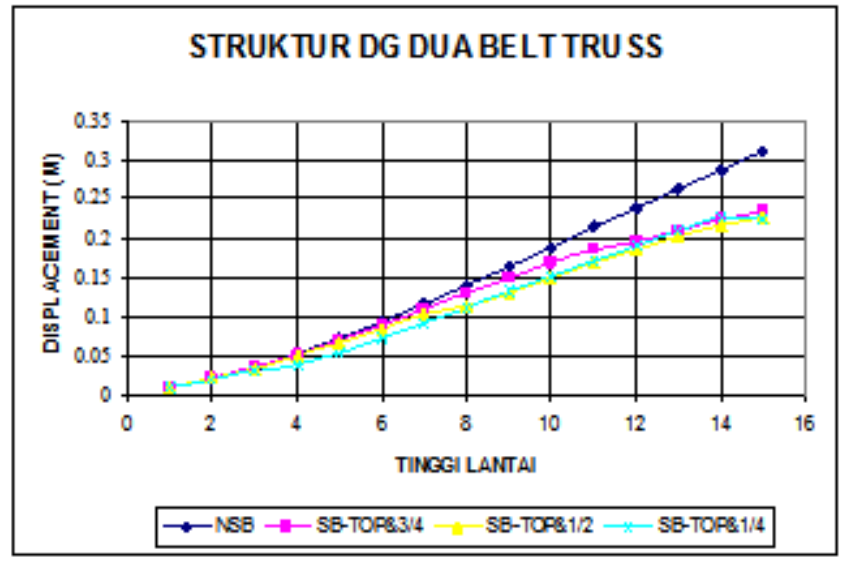

Gambar 7. Simpangan Lateral Model Struktur dengan dua Belt Truss

Perbandingan displacement untuk model struktur yang optimum untuk struktur dengan satu dan dua belt truss tampak pada gambar. 8, dimana dengan pemakaian dua belt truss terjadi reduksi simpangan lateral $10,42 \%$ terhadap pemakaian satu belt truss. 


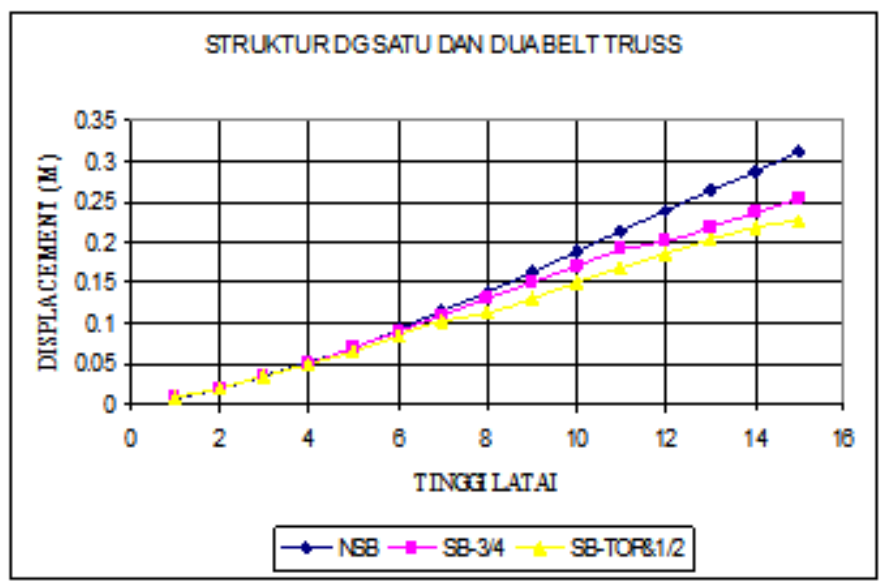

Gambar 8. Simpangan Lateral Model Struktur Optimum Dng Satu dan Dua belt truss

\section{KESIMPULAN}

Penggunaan Sistim Belt Truss pada bangunan tinggi dapat meningkatkan kekakukan struktur dan membuat struktur lebih efficient dibawah pengaruh beban lateral/gempa. Hasil perhitungan untuk struktur gedung 15 lantai ini, didapat bahwa model struktur rangka dinding geser dengan satu belt truss dapat mereduksi simpangan lateral maksimum sebesar 18,5\% dengan penempatan belt truss pada $3 / 4$ tinggi gedung, sedangkan dengan dua belt truss simpangan lateral maksimum yang dapat diredukai sebesar $27,01 \%$ yakni dengan penempatan belt truss pada lantai atas dan pada $1 / 2$ tinggi bangunan.

\section{DAFTAR PUSTAKA}

Badan Standarisasi Nasioanal, 2002, Tatacara Perhitungan Struktur Beton Untuk Bangunan Gedung, SNI 032847-2013.

Badan Standarisasi Nasioanal, 2002, Tatacara Perencanaan Ketahanan Gempa Untuk Bangunan Gedung, SNI 03-1726-2012.

Departemen Pekerjaan Umum, 1983, Peraturan Pembebanan Indonesia Untuk Gedung 1983.

Iyengar, Hal, 1995, Composite and Steel High Rise Systems. Habitat and The High-Rise, Tradition \& Innovation. In Proceedings of The Fifth World Congress. 14-19 May 1995. Amsterdam, The Netherlands, Bethlehem, Pa : Council on Tall Building and Urban Habitat, Lehigh University.

Lumantarna, B., Francisca, dan Rosilawati,1999, Perilaku Belt Truss sebagai Virtual Outrigger, Prosiding Seminar HAKI.

Lumantarna, B., 2001, The Effectiveness of Belt Truss As Virtual Outrigger for Tall Building, Proceedings ICCMC/IBST 2001 International Conference on Advanced Technologies in Design, Construction and Maintenance of Concrete Structures.

Nair, R.S., 1998, Belt Trusses and Basements as "Virtual" Outriggers for Tall Buildings, Engineering Journal, AISC, Fourth Quarter/1998 pp 140-146.

Schueller, Wolfgan., 1989, Struktur Bangunan Bertingkat Tinggi, Bandung : Penerbit PT. Eresco.

Stanfford Smith, Bryan., Coull, Alex.., 1991, Tall Building Structures : Abalysis Abd Design, John Wiley \& Sons, Inc.

Smith B.S et al, 1996, Offset Outrigger Concepts for Tall Building Structures. Tall Building Structure-A World View. In Proceedings of 67th Regional Conference in Conjunction with ASCE Structures Congress XIV.15-18 April 1996, Chicago, Illinois, USA. Bethlehem, Pa : Council on Tall Building and Urban Habitat, Lehigh University. 
Suku, Y.L., 2015, Evaluasi Kinerja Struktur Gedung Kantor Rektorat Universitas Flores Berdasarkan Pembebanan Gempa SNI 03-1726-2012, Majalah Ilmiah Indikator, 17(2) pp 78-92.

Taranath, Bungale S., 1998, Steel, Concrete, And Composite Design Of Tall Buildings, Second Edotion, McGraw-Hill

Xiaoxuan Qi and Shuang Chen, 1996, Design Issues Associated with Outriggers in Concrete High-Rise Buildings. Tall Building Structure-A World View. In Proceedings of 67th Regional Conference in Conjunction with ASCE Structures Congress XIV. 15-18 April 1996. Chicago, Illinois, USA. Betlehem, Pa: Council on Tall Building and Urban Habitat, Lehigh University. 